\title{
HUBUNGAN ANTARA VAGINOSIS BAKTERIAL DAN PERSALINAN PRETERM
}

\author{
Hepta Lidia ${ }^{1}$, Ova Emilia ${ }^{2}$, Moch. Anwar ${ }^{3}$
}

\begin{abstract}
Background: Preterm birth remain becomes global issue due to its contribution on high neonatal mortality rate. WHO (2012) estimated 15 million babies are born premature and Indonesia as one of 10 countries with highest rates of preterm birth (15,5/100 live births). In the poorest countries, on average, $12 \%$ of babies are born too soon compared with $9 \%$ in higher-income countries. Approximately $50 \%$ of spontaneous preterm birth is associated with genital infection. Plenty of efforts had been done to detect risk factor early, however if has not successfully decreased preterm birth rate. Because of that, it is a needed to do early screening of lower genital tract in pregnant woman to prevent preterm birth.
\end{abstract}

Method: Cross sectional

Location of study: Senopati Bantul hospital and Sewon community health center

Result and Discussion: This study involved 134 pregnant woman. Bivariate and multivariate analysis result showed that bacterial vaginosis, increased preterm birth significantly (OR 4,26; IK 95\% 1,16-15,62). Other risk factor that increased preterm birth are history of preterm birth (OR 11,16; IK 95\% 1,32-94,45).

Conclusion: Proportion of bacterial vaginosis in preterm birth significantly higher, compare to fullterm birth. History of preterm birth in last pregnancy significantly increased the number of preterm birth.

Keywords: Preterm Birth - bacterial vaginosis - early screening

\section{ABSTRAK}

Latar Belakang: Persalinan preterm masih menjadi masalah global oleh karena memberikan kontribusi pada kematian bayi yang cukup tinggi, WHO (2012) memperkirakan 15 juta bayi lahir preterm dan Indonesia termasuk salah satu dari 10 negara dengan angka persalinan preterm tertinggi (15,5/100 kelahiran hidup). Di negara-negara miskin, rata-rata $12 \%$ bayi lahir preterm dibandingkan $9 \%$ di negara berpendapatan lebih tinggi. Diperkirakan $50 \%$ dari kelahiran prematur spontan terkait dengan infeksi saluran genital. Banyak upaya yang telah dilakukan untuk mendeteksi risiko secara dini selain juga intervensi medis, namun belum banyak menurunkan kejadian persalinan preterm. Oleh karena itu perlu dilakukan suatu skrining awal untuk infeksi saluran genital bawah pada wanita hamil untuk mencegah persalinan preterm

Metode: cross sectional

Tempat penelitian: RSUD Senopati Bantul dan Puskesmas Sewon

Hasil dan Pembahasan: Penelitian melibatkan 134 ibu hamil. Hasil analisis bivariat dan multivariat menunjukkan bahwa vaginosis bakterial meningkatkan kejadian persalinan preterm secara signifikan (OR 2,70; IK 95\% 1,29-5,67). Faktor risiko lainnya yang meningkatkan persalinan preterm secara signifikan adalah riwayat persalinan preterm pada kehamilan sebelumnya (OR 11,16; IK 95\% 1,32-94,45).

Kesimpulan: Kejadian vaginosis bakterial pada persalinan preterm secara signifikan lebih tinggi dibandingkan pada persalinan aterm. Demikian juga riwayat persalinan preterm pada kehamilan sebelumnya secara signifikan meningkatkan risiko kejadian persalinan preterm.

Kata kunci: Persalinan preterm - vaginosis bakterial - skrining awal

$\overline{1,2,3}$ Bagian Obstetri dan Ginekologi FK UGM/RSUP Dr. Sardjito Yogyakarta 


\section{PENDAHULUAN}

Berdasarkan data yang diperoleh dari World Health Organization (WHO) [2012] diperkirakan sebanyak 15 juta bayi lahir preterm dan angka ini akan terus meningkat. Sekitar satu juta bayi diperkirakan meninggal setiap tahunnya akibat komplikasi persalinan preterm. Data dari WHO (2012) mencantumkan Indonesia sebagai salah satu dari 10 negara dengan angka persalinan preterm tertinggi (15,5/100 kelahiran hidup). ${ }^{1}$

Persalinan preterm meningkatkan kematian perinatal sebesar $65-75 \%$. Bayi preterm yang bertahan hidup akan mengalami morbiditas serius jangka pendek maupun jangka panjang., ${ }^{2,3}$

Perkembangan teknologi kedokteran pada dekade terakhir ini belum mampu menurunkan insidensi komplikasi akut dan kronik sejak pertengahan tahun 1990-an. ${ }^{4}$

Diperkirakan 50\% dari kelahiran preterm spontan terkait dengan infeksi saluran genital. ${ }^{5}$ Infeksi pada vagina merupakan faktor risiko persalinan preterm yang paling kuat. ${ }^{6}$ Banyak mikroorganisme menyebabkan infeksi simptomatik maupun asimptomatik dan dapat menyebabkan persalinan preterm. ${ }^{7}$ Kolonisasi bakteri memicu respon maternal maupun fetal yang akan menginisiasi rangkaian kejadian yang menyebabkan persalinan preterm. ${ }^{8}$

Standar diagnosis vaginosis bakterial menurut United States Preventive Services Task Force [USPTF] (2008) adalah gambaran klinis dan pewarnaan gram dari apusan cairan serviks dan vagina. ${ }^{9}$

Berbagai upaya telah dilakukan untuk mendeteksi dini infeksi intrauterin. Akan tetapi upaya ini belum dapat menurunkan kejadian persalinan preterm, maka perlu dilakukan skrining infeksi saluran genital bawah pada wanita hamil untuk mencegah terjadinya persalinan preterm tersebut.
Tujuan dari penelitian ini adalah mengetahui hubungan kejadian vaginosis bakterial pada persalinan preterm.

\section{METODE}

Jenis penelitian adalah analitik observasional dengan rancangan penelitian potong lintang. Penelitian ini mengambil subyek penelitian dengan consecutive sampling seluruh pasien yang bersalin di Puskesmas Sewon dan RSUD Senopati Bantul yang bersedia mengikuti penelitian dan memenuhi kriteria inklusi. Subyek penelitian dibagi menjadi 2 kelompok, yaitu kelompok persalinan preterm dan persalinan aterm. Kriteria eksklusi adalah a. pasien dengan penyakit penyerta dalam kehamilan (misal: hipertensi, preeklampsia, eklampsia, diabetes mellitus, penyakit jantung, asma bronkiale, gangguan tiroid), b. Pasien dengan kehamilan ganda atau janin lebih dari satu dan c. pasien dengan kelainan janin kongenital. Penelitian dilaksanakan pada bulan Januari hingga Desember 2011.

Variabel bebas adalah vaginosis bakterial. Variabel tergantung adalah persalinan preterm. Variabel luar adalah umur, pendidikan, paritas, jarak kehamilan, riwayat persalinan preterm, riwayat penyakit gigi dan mulut dan stres.

Vaginosis bakterial didiagnosis dengan melakukan pengecatan gram pada sampel cairan vagina, interpretasi hasil secara kualitatif menggunakan kriteria Hay-Ison.

\section{Uji Statistik dan Analisis Data}

Uji statistik yang digunakan dalam penelitian ini adalah risiko relatif dan regresi logistik.

Instrumen penelitian ada dua, yaitu wawancara terstruktur menggunakan kuisioner dan pemeriksaan laboratorium sederhana dengan apus cairan vagina.

Kuesioner penelitian terdiri dari kuesioner faktor risiko dan faktor stres. Kuesioner faktor 
risiko akan menilai faktor risiko terhadap terjadinya persalinan preterm. Kuesioner faktor stress akan dinilai dengan cara menghitung perceived stress scale (PSS) dari Cohen.

Pemeriksaan laboratorium apus cairan vagina dilakukan dengan mengambil cairan vagina dengan lidi kapas, dioleskan di gelas obyek, kemudian dikirimkan ke laboratorium RSUD Bantul. Data yang sudah dihimpun dikelola dan dianalisis dengan menggunakan program SPSS seri 16.

\section{HASIL DAN PEMBAHASAN}

Dari data yang terkumpul diperoleh 58 ibu melahirkan pada umur kehamilan preterm dan 76 ibu melahirkan pada umur kehamilan aterm. Hasil pemeriksaan vaginosis bakterial menunjukkan bahwa prevalensi pasien dengan vaginosis bakterial adalah $38,1 \%$.

Tabel 1. menunjukkan, karakteristik subyek penelitian. Tabel 2. menunjukkan perbandingan antara kedua kelompok penelitian di atas tidak

TABEL 1. Karakteristik sampel penelitian

\begin{tabular}{|c|c|c|}
\hline Karakteristik & Jumlah (n) & Persentase (\%) \\
\hline \multicolumn{3}{|l|}{ Vaginosis Bakterial } \\
\hline Positif & 51 & 38,1 \\
\hline Negatif & 83 & 81,9 \\
\hline \multicolumn{3}{|l|}{ Umur } \\
\hline$\geq 35$ tahun & 25 & 18,7 \\
\hline$<35$ tahun & 109 & 81,3 \\
\hline \multicolumn{3}{|l|}{ Pendidikan } \\
\hline Rendah & 120 & 89,6 \\
\hline Tinggi & 14 & 10,4 \\
\hline \multicolumn{3}{|l|}{ Paritas } \\
\hline Tinggi & 27 & 20,1 \\
\hline Rendah & 94 & 70,1 \\
\hline Missing & 13 & 9,7 \\
\hline \multicolumn{3}{|l|}{ Jarak Kehamilan } \\
\hline Dekat & 10 & 7,5 \\
\hline Jauh & 47 & 35,1 \\
\hline Missing & 13 & 9,7 \\
\hline Primigravida & 64 & 47,7 \\
\hline \multicolumn{3}{|l|}{ Riwayat Preterm } \\
\hline Ada & 9 & 6,7 \\
\hline Tidak ada & 125 & 93,3 \\
\hline \multicolumn{3}{|c|}{ Riwayat penyakit gigi mulut } \\
\hline Ada & 74 & 55,2 \\
\hline Tidak ada & 57 & 42,5 \\
\hline Missing & 3 & 2,2 \\
\hline \multicolumn{3}{|l|}{ Tingkat Stres } \\
\hline Tinggi & 44 & 32,8 \\
\hline Rendah & 81 & 60,4 \\
\hline Missing & 9 & 6,7 \\
\hline
\end{tabular}


menunjukkan perbedaan bermakna $(p>0,05)$ baik dari umur, pendidikan, paritas, jarak kehamilan, riwayat persalinan preterm sebelumnya dan tingkat stress. Pada riwayat penyakit gigi dan mulut, didapatkan perbedaan bermakna $(p<0,05)$ antara kedua kelompok.
Tabel 3. menunjukkan vaginosis bakterial pada wanita hamil akan meningkatkan kejadian persalinan preterm dengan risiko relatif 1,74 kali (IK 95\% 1,19-2,55).

TABEL 2. Komparabilitas variabel antar kelompok vaginosis bakterial dan kelompok tidak vaginosis bakterial

\begin{tabular}{|c|c|c|c|c|c|}
\hline \multirow{2}{*}{ Karakteristik } & \multicolumn{2}{|c|}{ Vaginosis Bakterial } & \multicolumn{2}{|c|}{$\begin{array}{l}\text { Tidak Vaginosis } \\
\text { Bakterial }\end{array}$} & \multirow[t]{2}{*}{$\mathbf{p}$} \\
\hline & $\mathbf{n}$ & $\%$ & $\mathbf{N}$ & $\%$ & \\
\hline \multicolumn{6}{|l|}{ Umur } \\
\hline$\geq 35$ tahun & 7 & 13,7 & 18 & 21,7 & 0,25 \\
\hline$<35$ tahun & 44 & 86,3 & 65 & 78,3 & \\
\hline \multicolumn{6}{|l|}{ Pendidikan } \\
\hline Rendah & 47 & 92,2 & 73 & 88,0 & 0,44 \\
\hline Tinggi & 4 & 7,8 & 10 & 12,0 & \\
\hline \multicolumn{6}{|l|}{ Paritas } \\
\hline Tinggi & 10 & 22,2 & 17 & 22,4 & 0,99 \\
\hline Rendah & 35 & 77,8 & 59 & 77,6 & \\
\hline \multicolumn{6}{|c|}{ Jarak Kehamilan } \\
\hline Dekat & 2 & 8,3 & 8 & 24,2 & 0,12 \\
\hline Jauh & 22 & 91,6 & 25 & 75,8 & \\
\hline \multicolumn{6}{|c|}{ Riwayat Preterm } \\
\hline Ada & 5 & 9,8 & 4 & 4,8 & 0,27 \\
\hline Tidak ada & 46 & 90,2 & 79 & 95,2 & \\
\hline \multicolumn{6}{|c|}{$\begin{array}{l}\text { Riwayat penyakit gigi } \\
\text { mulut }\end{array}$} \\
\hline Ada & 21 & 42,0 & 53 & 65,4 & 0,01 \\
\hline Tidak ada & 29 & 58,0 & 28 & 34,6 & \\
\hline \multicolumn{6}{|l|}{ Tingkat stress } \\
\hline Ada & 21 & 43,8 & 23 & 29,9 & 0,11 \\
\hline Tidak ada & 27 & 56,2 & 54 & 70,1 & \\
\hline
\end{tabular}


TABEL 3. Hubungan antara vaginosis bakterial dengan persalinan preterm

\begin{tabular}{cccccccc}
\hline \multirow{2}{*}{ Vaginosis Bakterial } & \multicolumn{3}{c}{ Persalinan Preterm } & \multicolumn{2}{c}{ Persalinan Aterm } & \multicolumn{3}{c}{ Analisis Bivariat } \\
\cline { 2 - 8 } & $\mathbf{n}$ & $\mathbf{\%}$ & $\mathbf{n}$ & $\mathbf{\%}$ & $\mathbf{R R}$ & IK 95\% & $\mathbf{p}$ \\
\hline Positif & 30 & 51,7 & 21 & 27,6 & 1,74 & $1,19-2,55$ & 0,004 \\
Negatif & 28 & 48,3 & 55 & 72,4 & & & \\
\hline
\end{tabular}

TABEL 4. Hubungan antara variabel pengganggu dengan variabel tergantung

\begin{tabular}{|c|c|c|c|c|c|c|c|}
\hline \multirow{2}{*}{ Variabel Pengganggu } & \multicolumn{2}{|c|}{$\begin{array}{l}\text { Persalinan } \\
\text { Preterm }\end{array}$} & \multicolumn{2}{|c|}{ Persalinan Aterm } & \multicolumn{3}{|c|}{ Analisis Bivariat } \\
\hline & $\mathbf{n}$ & $\%$ & $\mathbf{n}$ & $\%$ & RR & IK 95\% & $\mathbf{p}$ \\
\hline \multicolumn{8}{|l|}{ Umur } \\
\hline$\geq 35$ tahun & 7 & 12,1 & 18 & 23,7 & 0,60 & $0,31-1,16$ & 0,09 \\
\hline$<35$ tahun & 51 & 87,9 & 58 & 76,3 & & & \\
\hline \multicolumn{8}{|l|}{ Pendidikan } \\
\hline Rendah & 50 & 86,2 & 70 & 92,1 & 0,73 & $0,44-1,20$ & 0,27 \\
\hline Tinggi & 8 & 13,8 & 6 & 7,9 & & & \\
\hline \multicolumn{8}{|l|}{ Paritas } \\
\hline Tinggi & 10 & 21,7 & 17 & 22,7 & 0,97 & $0,56-1,68$ & 0,91 \\
\hline Rendah & 36 & 78,2 & 58 & 77,3 & & & \\
\hline \multicolumn{8}{|l|}{ Missing } \\
\hline Jarak Kehamilan & 3 & 15,8 & 7 & 18,4 & 0,88 & $0,32-2,46$ & 0,81 \\
\hline Dekat & 16 & 84,2 & 31 & 81,6 & & & \\
\hline \multicolumn{8}{|l|}{ Jauh } \\
\hline Missing & 8 & 13,8 & 1 & 1,3 & 2,22 & $1,62-3,05$ & 0,004 \\
\hline Primigravida & 50 & 86,2 & 75 & 98,7 & & & \\
\hline \multicolumn{8}{|l|}{ Riwayat Preterm } \\
\hline Ada & 32 & 55,2 & 42 & 57,5 & 0,95 & $0,65-1,39$ & 0,79 \\
\hline Tidak ada & 26 & 44,8 & 31 & 42,5 & & & \\
\hline \multicolumn{8}{|l|}{$\begin{array}{l}\text { Riwayat penyakit } \\
\text { gigi mulut }\end{array}$} \\
\hline Ada & 20 & 39,2 & 24 & 32,4 & 1,19 & $0,78-1,82$ & 0,44 \\
\hline Tidak ada & 31 & 60,8 & 50 & 67,6 & & & \\
\hline
\end{tabular}

Tabel 4. menunjukkan riwayat persalinan preterm pada kehamilan sebelumnya meningkatkan kejadian persalinan preterm (RR 2,22; IK 95\% 1,62-3,05). Variabel umur (RR 0,60; IK 95\% 0,31-1,16), pendidikan (RR 0,73; IK 95\% 0,441,20), Paritas (RR 0,97; IK 95\% 0,56-1,68), jarak kehamilan (RR 0,88; IK 95\% 0,32-2,46), riwayat penyakit gigi dan mulut (RR 0,95; IK 95\% 0,651,39), dan tingkat stres (RR 1,19; IK 95\% 0,781,42 ) tidak memiliki hubungan bermakna dengan persalinan preterm. 
TABEL 5. Analisis bivariat hubungan antara variabel pengganggu dengan variabel bebas

\begin{tabular}{|c|c|c|c|c|c|c|c|}
\hline \multirow{2}{*}{ Variabel Pengganggu } & \multicolumn{2}{|c|}{ Vaginosis Bakterial } & \multicolumn{2}{|c|}{$\begin{array}{c}\text { Tidak Vaginosis } \\
\text { Bakterial }\end{array}$} & \multicolumn{3}{|c|}{ Analisis Bivariat } \\
\hline & $\mathbf{n}$ & $\%$ & $n$ & $\%$ & $\mathbf{R R}$ & IK 95\% & $\mathbf{P}$ \\
\hline \multicolumn{8}{|l|}{ Umur } \\
\hline$\geq 35$ tahun & 7 & 13,7 & 18 & 21,7 & 0,57 & $0,22-1,49$ & 0,25 \\
\hline$<35$ tahun & 44 & 86,3 & 65 & 78,3 & & & \\
\hline \multicolumn{8}{|l|}{ Pendidikan } \\
\hline Rendah & 47 & 92,2 & 73 & 88,0 & 0,60 & $0,48-5,43$ & 0,44 \\
\hline Tinggi & 4 & 7,8 & 10 & 12,0 & & & \\
\hline \multicolumn{8}{|l|}{ Paritas } \\
\hline Tinggi & 10 & 22,2 & 17 & 22,4 & 0,99 & $0,41-2,41$ & 0,99 \\
\hline Rendah & 35 & 77,8 & 59 & 77,6 & & & \\
\hline \multicolumn{8}{|l|}{ Missing } \\
\hline Jarak Kehamilan & 2 & 8,3 & 8 & 24,2 & 0,28 & $0,05-1,84$ & 0,12 \\
\hline Dekat & 22 & 91,6 & 25 & 75,8 & & & \\
\hline Jauh & & & & & & & \\
\hline \multicolumn{8}{|l|}{ Riwayat Preterm } \\
\hline Ada & 5 & 9,8 & 4 & 4,8 & 2,12 & $0,55-8,34$ & 0,27 \\
\hline Tidak ada & 46 & 90,2 & 79 & 95,2 & & & \\
\hline \multicolumn{8}{|c|}{ Riwayat penyakit gigi mulut } \\
\hline Ada & 21 & 42,0 & 53 & 65,4 & 0,38 & $0,19-0,79$ & 0,01 \\
\hline Tidak ada & 29 & 58,0 & 28 & 34,6 & & & \\
\hline \multicolumn{8}{|l|}{ Tingkat stres } \\
\hline Ada & 21 & 43,8 & 23 & 29,9 & 1,83 & $0,86-3,87$ & 0,11 \\
\hline Tidak ada & 27 & 56,2 & 54 & 70,1 & & & \\
\hline
\end{tabular}

Tabel 5. menunjukkan riwayat penyakit gigi dan mulut justru menurunkan kejadian vaginosis bakterial 0,38 kali (RR 0,38; IK 95\% 0,19-0,79). Variabel umur (RR 0,57; IK 95\% 0,22-1,49), pendidikan (RR 0,60;IK 95\% 0,48-5,43), Paritas (RR 0,99; IK 95\% 0,41-2,41), jarak kehamilan
(RR 0,28; IK 95\% 0,05-1,84), riwayat persalinan preterm (RR 2,12; IK 95\% 0,55-8,34), riwayat persalinan preterm dan tingkat stres (RR 1,83; IK 95\% 0,86-3,87) tidak memiliki hubungan bermakna dengan vaginosis bakterial. 
TABEL 6. Analisis Multivariat hubungan antara variabel bebas dengan variabel tergantung dikontrol dengan variabel pengganggu

\begin{tabular}{|c|c|c|c|c|c|c|c|}
\hline \multirow[t]{2}{*}{ Variabel } & \multicolumn{2}{|c|}{$\begin{array}{l}\text { Persalinan } \\
\text { Preterm }\end{array}$} & \multicolumn{2}{|c|}{$\begin{array}{l}\text { Persalinan } \\
\text { Aterm }\end{array}$} & \multicolumn{3}{|c|}{ Analisis Multivariat } \\
\hline & $\mathrm{n}$ & $\%$ & $\mathrm{n}$ & $\%$ & OR & IK 95\% & p \\
\hline \multicolumn{8}{|c|}{ Vaginosis Bakterial } \\
\hline Positif & 30 & 51,7 & 21 & 27,6 & 4,26 & $1,16-15,62$ & 0,03 \\
\hline Negatif & 28 & 48,3 & 55 & 72,4 & & & \\
\hline \multicolumn{8}{|c|}{ Riwayat Preterm } \\
\hline Ada & 8 & 13,8 & 1 & 1,3 & 11,16 & $1,32-94,45$ & 0,03 \\
\hline Tidak ada & 50 & 86,2 & 75 & 98,7 & & & \\
\hline \multicolumn{8}{|l|}{ Umur } \\
\hline$\geq 35$ tahun & 7 & 12,1 & 18 & 23,7 & 0,50 & $0,11-2,38$ & 0,39 \\
\hline$<35$ tahun & 51 & 87,9 & 58 & 76,3 & & & \\
\hline \multicolumn{8}{|c|}{ Jarak Kehamilan } \\
\hline Dekat & 3 & 15,8 & 7 & 18,4 & 1,09 & $0,15-7,99$ & 0,93 \\
\hline Jauh & 16 & 84,2 & 31 & 81,6 & & & \\
\hline \multicolumn{8}{|c|}{$\begin{array}{l}\text { Riwayat penyakit } \\
\text { gigi mulut }\end{array}$} \\
\hline Ada & 32 & 55,2 & 42 & 57,5 & 2,66 & $0,59-11,92$ & 0,20 \\
\hline Tidak ada & 26 & 44,8 & 31 & 42,5 & & & \\
\hline \multicolumn{8}{|l|}{ Tingkat Stres } \\
\hline Tinggi & 20 & 39,2 & 24 & 32,4 & 2,09 & $0,41-10,67$ & 0,38 \\
\hline Rendah & 31 & 60,8 & 50 & 67,6 & & & \\
\hline
\end{tabular}

Tabel 6. menunjukkan hasil analisis multivariat vaginosis bakterial berhubungan bermakna dengan persalinan preterm (OR 4,26; IK 95\% 1,16-15,62). Riwayat persalinan preterm juga menunjukkan hubungan bermakna dengan kejadian persalinan preterm (OR 11,16; IK $95 \%$ 1,32-94,45). Sedangkan umur, jarak kehamilan, riwayat penyakit gigi dan mulut dan tingkat stress tidak berhubungan bermakna dengan kejadian persalinan preterm.

\section{DISKUSI}

Vaginosis bakterial merupakan vaginitis paling umum pada wanita hamil maupun tidak hamil. Nelson dan Macones menemukan prevalensi vaginosis bakterial pada wanita yang tidak hamil adalah $15-30 \%$, sedangkan pada wanita hamil lebih tinggi yaitu $50 \%$ atau lebih. Prevalensi vaginosis bakterial bervariasi mulai dari $4 \%$ di negara maju dan $61 \%$ di negara berkembang. ${ }^{11}$ Prevalensi vaginosis bakterial pada penelitian ini adalah $38,1 \%$, sedikit lebih rendah dibandingkan penelitian sebelumnya.

Penelitian metaanalisis oleh Leitich et al. untuk mengevaluasi vaginosis bakterial sebagai faktor risiko persalinan preterm, mendapatkan hasil bahwa vaginosis bakterial meningkatkan risiko persalinan preterm lebih dari 2 kali lipat (OR 2,19; IK 95\% 1,54-3,12). ${ }^{12}$ Hasil metaanalisis tersebut sesuai dengan penelitian ini, dimana vaginosis bakterial meningkatkan persalinan preterm lebih tinggi yaitu 4,26 kali (OR 4,26; IK 95\% 1,16-15,62).

Riwayat persalinan preterm pada kehamilan sebelumnya seringkali dinyatakan sebagai prediktor yang paling kuat untuk terjadinya persalinan preterm di kehamilan berikutnya. ${ }^{6}$ 
Diperkirakan bahwa insidensi terjadinya persalinan preterm selanjutnya setelah 1 kali persalinan preterm meningkat hingga 14,3\% dan setelah 2 kali persalinan preterm meningkat hingga $28 \%{ }^{13}$ $\mathrm{Hal}$ ini sesuai dengan hasil yang didapatkan pada penelitian ini, dimana riwayat persalinan preterm pada kehamilan sebelumnya meningkatkan kejadian persalinan preterm 11,16 kali (OR 11,16; IK $95 \%$ 1,32-94,45).

Usia maternal diatas 35 tahun atau lebih, telah diketahui memiliki risiko yang lebih besar, baik dari perspektif maternal maupun fetal. Penelitian Hoque melibatkan 1945 wanita, untuk mengetahui hubungan usia dengan luaran persalinan, didapatkan usia maternal 35 tahun atau lebih meningkatkan kejadian persalinan preterm (OR 1,37; IK 95\% 1,01-1,86). ${ }^{14}$ Penelitian sebelumnya oleh Mahmoodi (2010) menunjukkan hasil sebaliknya, yaitu usia maternal tidak memiliki hubungan dengan persalinan preterm $(p=0,731) \cdot{ }^{15} \mathrm{Hal}$ ini sesuai dengan hasil penelitian ini yang menunjukkan umur tidak berhubungan bermakna dengan kejadian persalinan preterm dengan analisis bivariat (RR 0,60; IK 95\% 0,31$1,16)$ maupun analisis multivariat (OR 0,50 ; IK $95 \%$ 0,11-2,38).

Penelitian sebelumnya yang menghubungkan antara multiparitas dengan persalinan preterm oleh Shaikh et al. menunjukkan bahwa multiparitas meningkatkan persalinan preterm secara bermakna (OR 4,21 dan $p=0,035) \cdot{ }^{16}$ Penelitian lainnya yang menghubungkan paritas dengan persalinan preterm oleh Rayis et al. justru menunjukkan bahwa grandemultigravida tidak berhubungan dengan persalinan preterm (OR 1,95; IK 95\% 0,9-1). ${ }^{17}$ Hasil penelitian ini menunjukkan tidak didapatkan perbedaan yang bermakna antara paritas tinggi dengan paritas rendah untuk mengalami persalinan preterm (RR 0,97; IK 95\% 0,56-1,68).

Penelitian oleh Jandaghi et al. menunjukkan terdapat hubungan signifikan antara interval kehamilan yang pendek dan persalinan prematur, studi ini menunjukkan $69 \%$ dari wanita multipara yang melahirkan bayi prematur memiliki jarak kehamilan kurang dari 2 tahun dengan kelahiran bayi sebelumnya. ${ }^{18}$ Penelitian sebelumnya oleh Ekwo menunjukkan bahwa jarak kehamilan yang pendek (konsepsi kurang dari 6 bulan) tidak berhubungan dengan kejadian persalinan preterm baik pada wanita kulit putih (OR 1,67; IK 95\% 0,42-2,91) dan wanita kulit hitam (OR 1,52; IK 95\% 0,91-2,55). ${ }^{19}$ Hasil penelitian ini juga menunjukkan bahwa jarak kehamilan yang pendek tidak berhubungan secara signifikan dengan persalinan preterm (OR 1,09; IK 95\% $0,15-7,99)$.

Tingkat pendidikan ibu merupakan salah satu parameter untuk menilai kondisi sosial ekonomi seseorang. Dalam penelitian ini didapatkan tingkat pendidikan rendah tidak berhubungan bermakna dengan kejadian persalinan preterm (RR 0,73; IK 95\% 0,44-1,20). Hasil ini sesuai dengan penelitian oleh Nejad (2008) yang mendapatkan tingkat pendidikan tidak memiliki hubungan signifikan dengan kejadian persalinan preterm. ${ }^{20}$ Berbeda dengan penelitian oleh oleh Astolfi yang mendapatkan adanya hubungan bermakna antara tingkat pendidikan ibu dengan kejadian persalinan preterm (OR 1,09; IK 95\% $1,076-1,105){ }^{21}$

Penyakit gigi dan mulut dipandang sebagai salah satu faktor yang mempengaruhi persalinan preterm melalui endotoksin maupun faktor mikroba yang mengaktivasi sistem inflamasi. Penelitian oleh Kumar menunjukkan terdapat hubungan yang bermakna antara periodontitis dengan persalinan preterm (RR 2,72; IK 95\% 1,30-5,68). ${ }^{22}$ Penelitian lain yang dilakukan oleh Lohsoonthorn memberikan hasil yang berbeda. Hasil penelitian tersebut menyimpulkan bahwa 
penyakit gigi dan mulut tidak berhubungan dengan kejadian persalinan preterm (OR 1,2; IK $95 \%$ 0,67-2,16). ${ }^{23}$ Penelitian ini juga menunjukkan bahwa riwayat penyakit gigi dan mulut tidak berhubungan secara signifikan dengan persalinan preterm (OR 2,66; IK 95\% 0,59-11,92).

Kortisol yang dikenal sebagai hormon stres dikeluarkan sebagai respon terhadap stres. Penelitian oleh Hedegaard et al. (1996), menunjukkan bahwa tingkat stress yang tinggi berhubungan dengan persalinan preterm (RR 1,75; IK 95\% 1,20-2,54). ${ }^{24}$ Hasil yang berbeda didapatkan oleh Shaikh et al. (2011) yang menyimpulkan bahwa stres tidak terdapat hubungan yang bermakna antara stress dengan kejadian persalinan preterm (OR 0,96; IK 95\% 0,86-1,08). ${ }^{16}$ Penelitian ini juga memberikan hasil yang serupa, bahwa stress tidak berhubungan secara signifikan dengan kejadian persalinan preterm (OR 2,09; IK 95\% 0,41-10,67).

Penggunaan antibiotika dapat mempengaruhi luaran persalinan preterm, namun tidak disertakan dalam penelitian ini. Penelitian ini menganalisis faktor infeksi pada ibu hamil, namun terbatas pada vaginosis bakterial dan riwayat penyakit gigi dan mulut. Faktor infeksi lainnya juga dapat mempengaruhi kejadian persalinan preterm.

Vaginosis bakterial merupakan awal dari infeksi intrauterin, apabila tidak dilakukan manajemenyangadekuatakan terjadipenyebaran ke desidua, amnion dan infeksi sistemik fetal. ${ }^{2}$ Yudin dan Moneymerekomendasikan pemberian metronidazole 500 mg per-oral diberikan 2 kali sehari selama 7 hari atau klindamisin 300 mg per-oral diberikan 2 kali sehari selama 7 hari. Terapi topikal dengan klindamisin vaginal tidak direkomendasikan untuk vaginosis bakterial pada kehamilan. Pemeriksaan ulang harus dilakukan 1 bulan setelah pengobatan untuk memastikan kesembuhan pasien. ${ }^{25}$

\section{KESIMPULAN DAN SARAN}

Pada penelitian ini didapatkan kejadian persalinan preterm secara signifikan lebih tinggi pada wanita hamil dengan vaginosis bakterial. Riwayat persalinan preterm pada kehamilan sebelumnya juga meningkatkan risiko terjadinya persalinan preterm secara signifikan di kehamilan berikutnya.

Pemberian antibiotik yang adekuat bagi wanita hamil dengan vaginosis bakterial akan menurunkan risiko persalinan preterm dan berbagai komplikasi akibat persalinan preterm ini.

Menindaklanjuti hasil penelitian ini diperlukan manajemen yang komprehensif untuk mencegah terjadinya persalinan preterm dengan memperhatikan faktor-faktor risiko yang meningkatkan angka kejadian persalinan preterm.

Metode pemeriksaan yang lebih baik dapat meningkatkan pengenalan faktor-faktor yang mempengaruhi kejadian persalinan preterm. Penelitian lebih lanjut masih diperlukan untuk mencegah dan mengurangi kejadian persalinan preterm.

\section{DAFTAR PUSTAKA}

1. World Health Organization. Preterm Birth. Fact Sheet No. 363, November 2012.

2. Cunningham FG, McDonal PC, Gant NF, Levano KJ, Gilstrap LC, Hankins GDV. Preterm Birth. In William Obstetrics, 23rd ed. Connecticut, Mc-Graw Hill. 2010.

3. Honest $\mathrm{H}$, Forbes $\mathrm{CA}$, Duree $\mathrm{KH}$, Norman $\mathrm{G}$, Duffy SB, Tsourapas A, et al. Screening to prevent spontaneous preterm birth: systematic reviews of accuracy and effectiveness literature with economic modeling. Health Technology Assessment 2009 Vol.13 No 43. UK

4. Russel RB, Green NS, Steiner CA, Howse JL, Poschman K, Dias $\mathrm{T}$, et al. Cost of hospitalization for preterm and low birth weight infant in United States. Pediatrics 2007 Vol 120 No 1. 
5. Klein LL, Gibbs RS. Infection and Preterm Birth. In Obstet Gynecol. Clin N Am 2005: 32: 397-410.

6. Goffinet F. Primary predictors of preterm labour. $\mathrm{Br}$ J Obstet Gynecol 2005;112 Suppl 1:38-47.

7. Swadpanich $U$, Lumbiginon P, Prasertcharoensook W, Laopaiboon M. Antenatal lower tract infection screening and treatment programs for preventing preterm delivery. Cochrane Database Syst Rev. 2008.

8. Goldenberg RL, Culhane JF, lams JD. Epidemiolgy and causes of preterm birth. Lancet 2008:371:7584.

9. United States Preventive Services Task Force. Screening for Bacterial Vaginosis in Pregnancy to Prevent Preterm Delivery: U.S. Preventive Services Task Force Recommendation statement. Annals of Internal Medicine Clinical Guidelines 2008, 48:3

10. Ison CA dan Hay PE. Validation of a simplified grading of Gram stained vaginal smears for use in genitourinary medicine clinics. Sex Transm Infect 2002;78:413-415

11. Nelson DB, Macones G. Bacterial Vaginosis in Pregnancy: Current Findings and Future Directions. Epidemiol Rev 2002, 24(2): 102-108.

12. Leitich $H$, Borner-Adler B, Brunbauer $M$, Kaider $A$, Egarter $C$, Husslein P. Bacterial vaginosis as a risk factor for preterm delivery: A meta-analysis. Am J Obstet Gynecol 2003, 189: 139-47).

13. Chandraharan E, Arulkumaran S. Recent advances in management of preterm labor. India J Obstet Gynecol Vol. 55, No. 2, 2005 Pg 118- 124

14. Hoque ME. Advanced maternal age and outcomes of pregnancy: a retrospective study from South Africa. Biomed Research 2012, 23(2):281-285.

15. Mahmoodi Z, Hoseini F, Shahr HAS. The association between maternal factors and preterm birth and premature rupture of membranes. $J$ of Fam and Repro Health 2010, 4(3): 135-139.

16. Shaikh K, Premji SS, Rose MS. The association between parity, infant gender, higher level of paternal education and preterm birth in Pakistan: a cohort study. BMC Pregnancy and Childbirth 2011, 11:88.

17. Rayis DA, Ali AAA, Abbaker AO. Maternal and perinatal outcomes of grandmultiparity in Kassala hospital, Eastern Sudan. Khartoum Med J 2011, 4(1):554-557.

18. Jandaghi G, KhalajiniaZ, Moghadam PS. Contribution of Maternal Demographic and Medical Factors to the Risk of Prematurity in Qom Hospitals. Maced J Med Sci 2011, 1857-5773.

19. Ekwo EE, Moawad A. The relationship of interpregnancy interval to the risk of preterm births to black and white women. Int J of Epid 1998, 27:68-73.

20. Nejad VM, Shafaie S. The Association of Bacterial Vaginosis and Preterm Labor. J Pak Med Assoc 2008, 58: 104.

21. Astolfi P, Zonta LA. Risks of preterm delivery and association with maternal age, birth order, and fetal gender. Human Reproduction 1999, 14(11): 28912894.

22. Kumar A, Basra M, Rani V, Prasad S, Lamba AK, Verma $M$, Agarwal S, Sharma S. Association of Maternal Periodontal Health with Adverse Pregnancy Outcome. J Obstet Gynaecol Res 2013, 39(1):40-5.

23. Lohsoonthorn V, Kungsadalpipob K, Chanchareonsook $P$. Is maternal periodontal disease a risk factor for preterm delivery? Am J Epidemiol, 2009, 169:731-739.

24. Hedegaard M, Henriksen TB, Sechner NJ, Hatch M Sabroe S. Do Stressful Life Events Affect Duration of Gestation and Risk of Preterm Delivery? American Journal of Epidemiology 1996; 7:339-345

25. Yudin $\mathrm{MH}$ dan Money DM. Screening and Management of Bacterial Vaginosis in Pregnancy. SOGC Clinical Practice Guideline No. 211, August 2008. 